\title{
Response of Apis mellifera L colonies infested with Varroa jacobsoni Oud
}

\author{
O Boecking *, W Drescher \\ Institut für Landwirtschaftliche Zoologie und Bienenkunde der Universität, \\ Melbweg 42, 5300 Bonn 1, Germany
}

(Received 11 January 1991; accepted 25 April 1991)

\begin{abstract}
Summary - The response of $A$ mellifera colonies to Varroa-infested brood cells has been investigated. Using special combs which guaranteed that the structure of the cell cap remained undamaged in the process of infestation, we infested worker brood cells with 1 or 2 mites each. The artificially infested cells were detected, uncapped and removed to various degrees by the worker bees of different carnica strains. Brood cells infested with 1 mite were removed from $5.5 \%$ ( $\mathrm{min}$ ) up to $95.8 \%$ (max) those with 2 Varroa from $4.8 \%$ (min) up to $100 \%$ (max) till $10 \mathrm{~d}$ after infestation. Figure 1 shows the means of the removed brood cells infested with one mite. The removal rates of the 2 infestation levels differed $(P \leq 0.01)$. Those colonies with a high removal response to brood cells infested with 1 mite also showed a high removal response to brood cells infested with two mites and vice versa $(r=0.76 ; P \leq 0.001)$. Varroa mites escaped or were possibly killed. The signals which cause the removal are unknown. We do not know to what extent the method influences the magnitude of the removal behavior.
\end{abstract}

Apis mellifera / Varroa jacobsoni/ hygienic behavior

\section{INTRODUCTION}

The Asian honeybee Apis cerana Fabr achieves low mite infestation levels, presumably because the bee has evolved resistance to the Varroa mite. Some studies have given clues regarding the resistance mechanism. Rath and Drescher (1990) showed that the detecting, uncapping, and removal of Varroa-infested worker brood cells by the $A$ cerana workers is an important aspect of the resistance mechanism. Artificially-infested worker brood cells were removed to $\approx 98 \%$ within $5 \mathrm{~d}$. The removal response to Varroa-infested drone cells seems to be minimized due to the thick drone cocoon cap.

Highly infested drone cells also cause losses of Varroa mites since the dead drones are not removed (Koeniger, 1987). Peng et al (1987a) have suggested that the grooming behavior of the Asian honeybee is the reason for the low infestation level as the bees catch and kill Varroa with their mandibula. In experiments with hetero-specific colonies, $A$ cerana worker bees detected and removed Varroa mites

\footnotetext{
* Correspondence and reprints
} 
in $A$ mellifera worker brood (Peng et al, 1987b). A cerana bees reduce the pressure of Varroa parasitism by absconding (Woyke, 1976).

So far, investigations of possible resistance mechanisms of the European honeybees Apis mellifera $L$ have concentrated mainly on differential reproduction of the mite, brood attractivity and the postcapping stage (Ritter and De Jong, 1984; Ruttner et al, 1984; Moritz, 1985; Schousboe, 1986; Büchler, 1990).

In this paper we report the first results of our investigations regarding the reaction of $A$ mellifera colonies to Varroa-infested brood cells.

\section{MATERIALS AND METHODS}

The reaction of $A$ mellifera worker bees to Varroa-infested worker brood cells has been tested with special combs constructed with 1 cell layer only. Before using them in our tests the plastic foundations were completed with a wax structure by the bees. These combs permitted the infestation of several brood cells with Varroa mites after capping. As the cell bottoms had little plugs it was guaranteed that the structure of the cell cap remained undamaged in the process of infestation. In brood rearing colonies the queens were restricted to these combs for $24 \mathrm{~h}$ to lay eggs. After capping, the recently capped brood cells were marked on a clear plastic sheet. For successive controls these sheets could be readjusted to the same position. About 60 cells within one comb were infested with 1 or 2 Varroa mites which were collected from infested brood combs shortly after capping. Control cells were opened and closed without infesting any mites. These artifically-infested combs were placed into 51 different $A m$ carnica test colonies of 17 strains in the middle of the brood nest. The test colonies filled 2 regular 9 frame supers with $6-8$ brood combs. The origin of the A $m$ carnica colonies differed, but these differences were not considered in these investigations.

Five and $10 \mathrm{~d}$ after the artificial infestation, the brood removal reaction to these combs was recorded by using the clear plastic sheets mentioned above. The distinct position of the infested cells could be determined from the front side of the comb.

\section{RESULTS}

The infested worker brood cells were detected to various degrees by the worker bees, uncapped, and the infested larvae (pupae) removed. In a way this behavior is similar to other known kinds of brood removal.

After $10 \mathrm{~d}$, the removal of brood cells infested with 1 mite differed between the various carnica test colonies from $5.5 \%$ (min) up to $95.8 \%$ (max). Within the same colonies, brood cells infested with 2 Varroa mites showed a removal from $4.8 \%$ (min) to $100.0 \%$ (max). The removal rates of the 2 infestation levels differed significantly ( $P$ $\leq 0.01$ ). Figure 1 shows the means of the removed brood cells infested with 1 mite.

The control groups remained almost untouched. Only in those cases in which the mites entered a few control cells before the capping the worker bees removed them too. This happened because mites were already present to a small extent in the brood-rearing colonies. Faeces of the mites in these empty control cells served as an indication of their former presence. In former experiments which included 24-h checks of the artificially infested combs, most of the removed control cells were naturally infested (Boecking, 1990). Because of the assumption that some mites could have entered the cells before capping the results were corrected by using the Abbott formula (Abbott, 1925).

From the checks of the combs at the 5th and the 10th $d$ we were able to observe the progress of the removal response. Some colonies reacted to the different infestation levels during the entire investiga- 


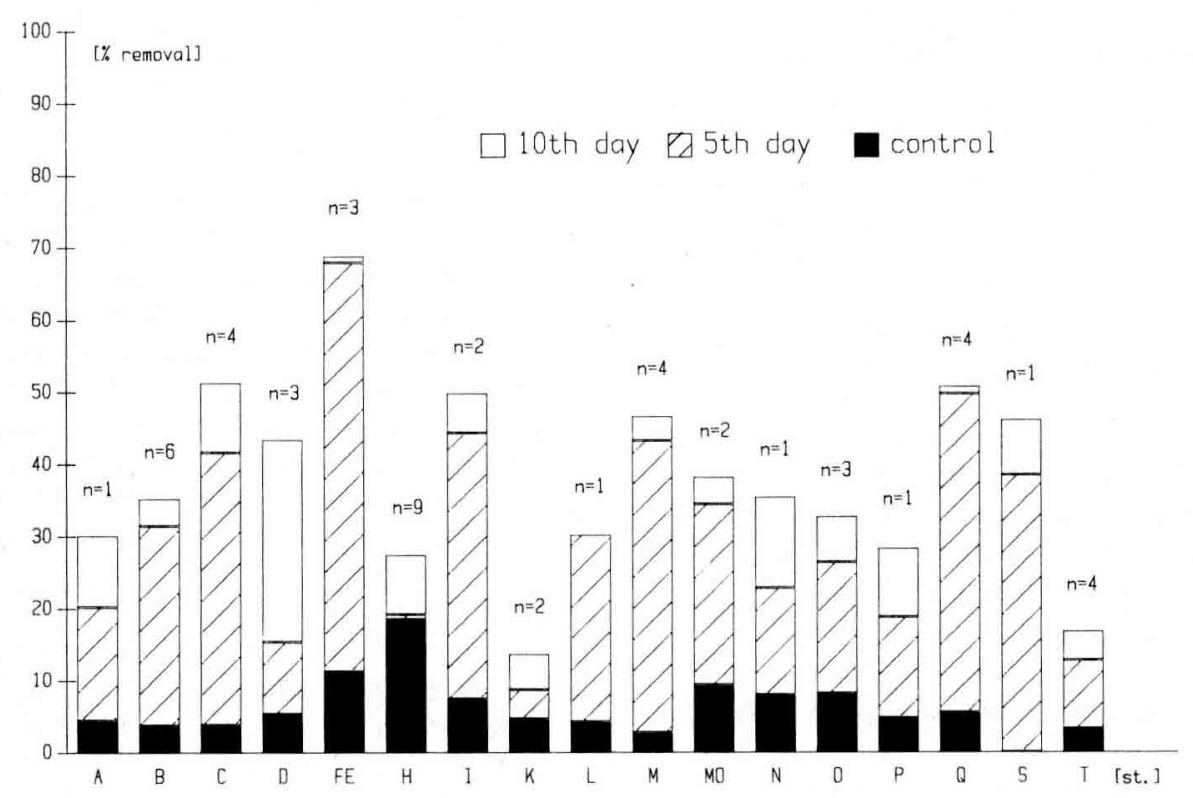

Fig 1. Removal response of $51 \mathrm{~A}$ mellifera colonies of 17 strains (st) to worker brood cells artificially infested with 1 Varroa mite and checked on the 5 th and 10 th $d$ after infestation.

tion period. Others responded only during the first days and did not pay attention to the remaining infested cells.

Moreover, those colonies which showed a high removal response to brood cells infested with one mite also removed brood cells infested with 2 mites to a high extent and vice versa $(r=0.76 ; P \leq 0.001)$.

After these tests we collected several dead and distinctively damaged Varroa mites from the hive debris. In a special test (using the method shown above) which guaranteed that no other insect or scavenger could enter the hive debris, we found 6 killed mites after infestation with 16 Varroa mites in a colony free of other mites. The mites showed injuries which may indicate that $A$ mellifera worker bees are able to kill the mites with their mandibula.

\section{DISCUSSION AND CONCLUSION}

The removal behavior of honeybees as a part of cleaning behavior has been described by Rothenbuhler (1964) in regard to American foulbrood, and by Rath and Drescher (1987) in regard to chalkbrood.

Our data show that $A$ mellifera bees are able to detect Varroa-infested worker brood cells. They react to a low infestation level by uncapping and removal of the infested larvae (pupae). The removal response increases to a slight extent with the infestation level/cell. The removal intensity of the colonies is significantly correlated with the infestation level.

The nature of the signals which cause the removal is unknown. We do not know 
to what extent the method influences the magnitude of the removal behavior.

In experiments not recorded in this paper, we found differences between the intensity of mite removal depending on the kind of comb (to be published). Under "flightroom" conditions we compared the response to naturally infested plastic and wax combs within 1 test colony. In plastic combs the bees removed on average $33.2 \%$ (SD 12.7) of $ø n=107$ cells infested with mites (5 repetitions); in natural wax combs they removed on average $17.6 \%$ (SD 8.2) of $\emptyset n=138$ cells infested with mites ( 6 repetitions). The results of these experiments could indicate that the plastic foundations of the 1-sided combs we used influence the removal behavior.

A mellifera bees also seem to be able to kill Varroa with their mandibula. In contrast to other observed resistance mechanisms (differential reproduction of the mite, postcapping stage and brood attractivity) which are predominantly bound to features of the brood, the removal of Varroainfested brood cells seems to be a mechanism demanding a selective activity on the part of the mellifera worker bees. To a minor extent, our data correspond with the data on $A$ cerana (Rath and Drescher, 1990).

\section{ACKNOWLEDGMENT}

The investigation was supported by the Ministry of Agriculture, Germany.

\footnotetext{
Résumé - Réaction de colonies d'Apis mellifera $L$ à des cellules de couvain parasitées par Varroa jacobsoni Oud. A l'aide de rayons spéciaux (une seule couche de cellules avec un petit bouchon dans le fond de chacune d'elles), nous avons infesté expérimentalement et indivi-
}

duellement des cellules de couvain d'ouvrières avec un nombre connu d'acariens tout en gardant intact l'opercule de la cellule et étudié la réaction de 51 colonies d' $A$ $m$ carnica. Les cellules de couvain parasitées artificiellement ont été détectées, désoperculées et nettoyées à divers degrés par les ouvrières. Les cellules parasitées par un seul varroa ont été nettoyées de $5,5 \%(\min )$ à $95,8 \%(\max )$, celles parasitées par 2 varroas de $4,8 \%$ (min) à $100 \%$ (max), au bout de $10 \mathrm{j}$. La figure 1 donne les taux moyens de nettoyage des cellules parasitées par un varroa pour les 17 lignées carnica étudiées. Les taux de nettoyage sont significativement différents ( $P$ $\leq 0,01)$ pour les 2 niveaux d'infestation. Les colonies qui présentaient une forte réaction de nettoyage aux cellules parasitées par un varroa ont montré également une forte réaction aux cellules parasitées par 2 varroas, et vice versa $(r=0,76 ; P \leq$ $0,001)$. Une partie des varroas évacués ont vraisemblablement été tués par les abeilles. Les signaux qui déclenchent le nettoyage restent inconnus. Nous ne savons pas dans quelle mesure la méthode utilisée influence l'intensité du comportement de nettoyage.

\section{Apis mellifera / Varroa jacobsoni / com- portement hygiénique}

\footnotetext{
Zusammenfassung - Reaktion von Apis mellifera $L$ Völkern auf Varroa infizierte Brutzellen. Durch die Verwendung von Spezialwaben, die eine experimentelle Infizierung einzelner Brutzellen mit einer definierten Anzahl von Varroa-Milben erlauben, ohne dabei den Bienen zugängliche Zellstrukturen zu manipulieren, wurde die Reaktion von 51 A m carnica Völkern auf Varroa infizierte Arbeiterinnenbrutzellen untersucht. Die Bienen reagierten auf die experimentell infizierten Brutzellen mit einem Putzverhalten, das ein Öffnen und
} 
Ausräumen der Bienenbrut umfasst. Einfach parasitierte Brutzellen wurden nach 10 Tagen Untersuchungszeit zu 5.5\% (min) bis $95.8 \%$ (max) ausgeräumt, zweifach parasitierte zu $4.8 \%$ bis $100 \%$ (max). Abbildung 1 zeigt die durchschnittlichen Ausräumraten der verwendeten CarnicaHerkünfte auf mit einer Milbe infizierten Brutzellen. Die Unterschiede zwischen den Ausräumreaktionen auf 1-fach und 2-fach infizierte Zellen sind signifikant $(P \leq 0.01)$. Völker, die 1-fach infizierte Brutzellen zu einem großen Teil ausräumten, taten dies auch bei 2-fach infizierten Zellen und umgekehrt ( $r=0.76 ; P \leq 0.001$ ). Ein Teil der ausgeräumten Milben wurde möglicherweise durch die Bienen getötet. Die Signale, die die Bienen zum Ausräumen der infizierten Zellen veranlassen, sind bisher unbekannt. Es ist denkbar, daß die hohen Ausräumraten in unseren Versuchen durch die Methode beeinflußt sind.

\section{Apis mellifera / Varroa jacobsoni / Putz- verhalten}

\section{REFERENCES}

Abbott WS (1925) A method of computing the effectiveness of an insecticide. $J$ Econ Ento$\mathrm{mol} 18,265-267$

Boecking O (1990) Brutattraktivitätsunterschiede verschiedener Bienenherkünfte für Varroa jacobsoni Oud im Labortest und das Putzverhalten von Apis mellifera L. Diplomarbeit, Georg-August-Universität, Göttingen

Büchler R (1990) AG-Tagung in Adelsdorf März 1990: Möglichkeiten zur Selektion auf erhöhte Varroa-Toleranz mitteleuropäischer Bienenherkünfte. Apidologie 21(4), 365-367
Koeniger N (1987) Die östliche Honigbiene und ihre Milbe Varroa jacobsoni. Imkerfreund 42, 303-306

Moritz RFA (1985) Heritability of the postcapping stage in Apis mellifera and its relation to varroatosis resistance. $J$ Hered 76, 267-270

Peng YS, Fang $Y, X u S, G e L$ (1987a) The resistance mechanism of the Asian honeybee, Apis cerana Fabr, to an ectoparasitic mite Varroa jacobsoni Oudemans. J Invertebr Pathol 49, 54-60

Peng YS, Fang Y, Xu S, Ge L, Nasr ME (1987b) Response of foster Asian honeybee (Apis cerana Fabr) colonies to the brood of European honeybee (Apis mellifera $L$ ) infested with parasitic mite, Varroa jacobsoni Oudemans. J Invertebr Pathol 49, 259-264

Rath W, Drescher W (1987) Krankheitsabwehr im Bienenvolk, untersucht an der Kalkbrutanfälligkeit genetisch unterschiedlichen Bienenmaterials. Allg Dtsch Imkerztg 21(5), 149152

Rath W, Drescher W (1990) Response of Apis cerana Fabr towards brood infested with Varroa jacobsoni Oud and infestation rate of colonies in Thailand. Apidologie 21, 311-321

Ritter W, De Jong D (1984) Reproduction of Varroa jacobsoni Oud in Europe, the Middle East and tropical South America. $Z$ Angew Entomol 98, 55-57

Ruttner F, Marx H, Marx G (1984) Beobachtungen über eine mögliche Anpassung von Varroa jacobsoni an Apis mellifera $L$ in Uruguay. Apidologie 15(1), 43-62

Rothenbuhler W (1964) Behavior genetics of nest cleaning behavior in honeybees. I. Responses of four inbred lines to disease killed brood. Anim Behav 12(4), 578-583

Schousboe C (1986) The duration of closed cell stage in worker brood of Danish honeybees (Apis mellifera $L$ ) in relation to increased resistance to the Varroa mite (Varroa jacobsoni Oud). Tidsskr Planteavl 90, 293-299

Woyke J (1976) Brood rearing efficiency and absconding in Indian honeybees. $J$ Apic Res $15,133-143$ 